Article

\title{
Planning Considerations of Managed Aquifer Recharge (MAR) Projects in Jordan
}

\author{
Elias Salameh ${ }^{1, * \mathbb{D}}$, Ghaida Abdallat ${ }^{1}$ and Michael van der Valk ${ }^{2}$ \\ 1 National Center for Research and Development (NCRD), Amman 11941, Jordan; ghidaaabdallat@yahoo.com \\ 2 Hydrology.nl-International Hydrology and Water Resources, P.O. Box 61003, NL-1005 HA Amsterdam, \\ The Netherlands; info@hydrology.nl \\ * Correspondence: salameli@ju.edu.jo; Tel.: +96-279-539-7766
}

Received: 25 September 2018; Accepted: 19 December 2018; Published: 22 January 2019

\begin{abstract}
This work discussed the conditions for the successful implementation of managed aquifer recharge, with various case studies in Jordan. The motivation behind this study was that many managed aquifer projects have been implemented in Jordan without adequate studies and they have since failed. Examples from Jordan were provided to serve as an illustration of Middle Eastern and North African countries, with their semi-arid to arid climates and increasing demand for water. The methodology included the evaluation of the implemented managed aquifer projects in Jordan and whether they achieved success or failure in fulfilling the purposes of aquifer recharging, as well as to clarify the reasons for the failure or success. The results showed that a minimum level of study must be carried out before starting any artificial recharge projects, such as defining the aquifer parameters and the water quality evolution after recharge, in addition to understanding of the fate of the recharged water. Managed aquifer recharge can alleviate the impacts of climate change by making use of unused water, and in the case of Jordan, it can alleviate the implications of dropping groundwater levels.
\end{abstract}

Keywords: managed aquifer recharge (MAR); pre-conditions; success; Middle East; North Africa

\section{Introduction}

Global overexploitation of groundwater resources is gradually leading to aquifer depletion. In addition, climate change is negatively affecting certain areas of the globe, expressed by lower precipitation amounts and increasing temperatures. Overexploitation and climate change lead to two major physical impacts, i.e., aquifer depletion and groundwater quality degradation by the mobilization of saline water bodies. Both impacts lead to the degradation of available resources and rigorous negative implications for the supplies. If nothing is done about the depletion and degradation of groundwater, it becomes imperative to develop new sources to cover demand and to prevent water supply shortages or deteriorating water quality. Harm to groundwater negatively impacts water supplies for agriculture, industry, and household use. Decreasing irrigation water quantities and deteriorating water quality results in lower income for farmers, increasing unemployment, increasing poverty, diminishing food security, etc., which represent 'social time bombs.' The negative impacts to domestic/household and agricultural water supplies reduces the quality and quantity of available water and can lead to poor health and societal instability, as has been the case in Syria and Iraq during years of conflict [1-3].

Managed aquifer recharge (MAR), or technology described by terms such as "aquifer storage and recovery (ASR)", "artificial recharge", and "rainwater harvesting" is an option to adapt to climate change, especially when such changes are expected to negatively affect the availability of water in arid and semi-arid countries. 
MAR is a way to save collected water from evaporation and from the pollution that surface water bodies are exposed to. In addition, during winter, most of the treated wastewater is unused because there are, in general, no storage facilities provided for it. Therefore, it also becomes available for potential recharge.

The Dead Sea level has been declining for decades [4-7], along with the groundwater levels and stocks within its catchment. MAR may help to alleviate these impacts and their implications to water supplies, as well as the social, economic, and political implications.

MAR is the man-made intentional enhancement of groundwater recharge in a certain area, irrespective of the methods used to increase that amount $[8,9]$.

The options to avoid over-exploitation and climatic changes (partially) are limited to enhancing groundwater recharge and ending over-exploitation by reducing demand or developing other water sources. The latter, if targeted without intensive socio-economic and political preparations and planning, will certainly result in social and economic miseries, as well as political unrest.

A relatively large number of publications are available on artificial groundwater recharge and river bank storage, site identification, methods of recharge, pollutants removal, along with case studies [8-20]. However, reports on the reasons for the success or failure of such projects are very limited. Hence the relevance of the current study.

Managed groundwater artificial recharge projects are quite common and river bank infiltration and storage projects are found globally, especially in Europe [21-24]. Additionally, the use of artificial recharge to store and treat wastewater, as well as halting salt water intrusions is adequately reported in the literature $[25,26]$.

In the Middle East, managed aquifer recharge has become a necessity within the integrated water management concepts that these countries are striving to achieve [18]. This involves developing water resources from times of availability to times of need, thereby alleviating water supply problems, even as a measure to mitigate against climate change. Such interventions will certainly not reverse climate change, but they can alleviate the immediate negative impacts on water supply.

In arid and semi-arid areas, underground water storage is preferable to surface storage because of the:

- Minimization of evaporation losses compared to surface storage.

- Prevention from direct pollution and pollution accidents.

- Prevention of eutrophication.

- A relatively inexpensive way to store water.

- Improvement of groundwater quality in many areas.

- Further water treatment for some biologically impaired recharge water qualities.

Within the United States Agency for International Development (USAID)-funded project "Acceleration of Aquifer Storage and Recovery in the MENA Region", an overview has been made of the previous and current aquifer recharge and related projects in Jordan. Not all projects have served the initial intentions. In some cases, dams and associated reservoirs intended for drinking water and irrigation, have unintentionally recharged aquifers. In other cases, projects that started as groundwater recharge projects have been turned into irrigation and drinking water projects due to a lack of infiltration. In this paper, we give examples of attempts at artificial aquifer recharge projects in Jordan, with some lessons learned that might be beneficial for similar projects in comparable hydrogeological and climatological settings, for example, in the Middle East and North Africa.

\section{Materials and Methods}

Artificial groundwater recharge projects in Jordan, whether planned for recharge or those which were not intended for that purpose but ended up being useful for artificial recharge, were critically evaluated using geologic, hydrologic, and hydrogeological methodologies. From that evaluation, the geologic, hydrologic, and hydrogeological conditions for the planning of successful artificial recharge 
projects were derived. A successful MAR project should serve the objectives it was planned for; therefore, the evaluation of potential sites for MAR in Jordan was delineated.

MAR guidelines and conditions in regions like the USA [27], Europe [22,23,25], and others [28-34] were studied and assessed for the conditions of their suitability for Jordan. In addition, MAR techniques using recharge pools, dams, weirs, excess irrigation, and wells, etc., were studied from the perspective of Jordan's water types, qualities, topography, and climate.

The quantities and qualities of potential recharge waters, such as flood, treated waste water, and excess base flows have been studied to evaluate their adequacy for recharge. Recharge sites were evaluated based on the present land use and suitability for recharge. The geological set-up of potential recharge sites, the availability of rechargeable aquifers in extension, and the potential uptake of recharge water were studied using geologic, surface, and subsurface mapping by evaluating borehole logs and geoelectric soundings. The fate of recharge water, if left under natural conditions compared to its fate when recharged into aquifers, was also evaluated for the eastern parts of the country.

\section{Factors to Consider When Siting and Designing Mar Facilities and Programs for Arid Regions}

As a result of previous MAR evaluations, it was found that a variety of conditions should be considered during the design and planning to ensure a successful national or large-scale MAR program. The conditions were worked out during this study and are discussed in Table 1. In addition, for the successful implementation of the MAR, a set of steps must be performed, as depicted in Figure 1.

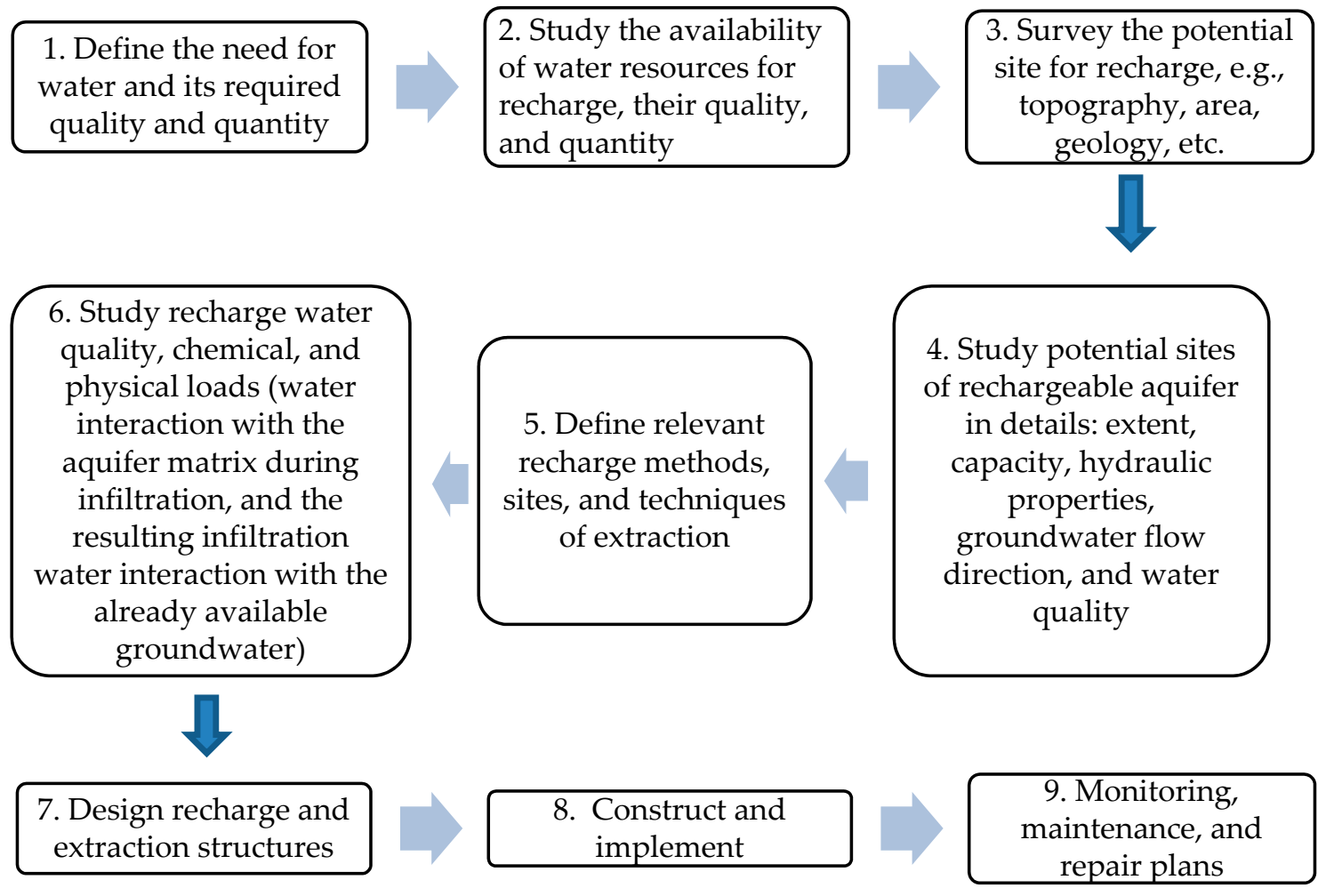

Figure 1. Flow chart of MAR design considerations. 
Table 1. Critical factors in the designing and implementing of the Managed aquifer recharge (MAR) program.

\begin{tabular}{|c|c|}
\hline $\begin{array}{l}\text { Purpose of } \\
\text { Enhanced } \\
\text { Recharge }\end{array}$ & $\begin{array}{l}\text { - } \quad \text { Store water from times of abundance to times of need. } \\
\text { - } \quad \text { Build or augment reserves. } \\
\text { - } \quad \text { Recharge as a means of additional water treatment. } \\
\text { - } \quad \text { Improvionement of water quality by mixing. } \\
\text { - } \quad \text { Prevention of aquifer compaction. }\end{array}$ \\
\hline $\begin{array}{l}\text { Availability of } \\
\text { Suitable Water } \\
\text { for Recharge }\end{array}$ & $\begin{array}{l}\text { - } \quad \text { Timing of supply. } \\
\text { - } \quad \text { Quantity of supply. } \\
\text { - } \quad \text { Distance from area of water use and elevation differences. } \\
\text { - Water quality. }\end{array}$ \\
\hline $\begin{array}{l}\text { Conditions in } \\
\text { the Receiving } \\
\text { Aquifer }\end{array}$ & $\begin{array}{l}\text { - } \quad \text { Available land in locations with otherwise high MAR potential. } \\
\text { - } \quad \text { Quality of recharge water. } \\
\text { - } \quad \text { Potential geohydro-chemical interactions. } \\
\text { - } \quad \text { Ease of recharging/abstracting recharge water. }\end{array}$ \\
\hline Site Conditions & $\begin{array}{l}\text { - } \quad \text { Availability of roads, electricity, and communications. } \\
\text { - } \quad \text { Institutional ability to control site. } \\
\text { - } \quad \text { Distance from end use of water. }\end{array}$ \\
\hline $\begin{array}{l}\text { Methods of } \\
\text { Recharge and } \\
\text { Abstraction }\end{array}$ & $\begin{array}{l}\text { - Pre-recharge treatment requirements: filtration, sediment removal, chemical } \\
\text { - } \quad \text { Rechditioning, etc. } \\
\text { - } \quad \text { Extraction methods: Wells, galleries, flow to stream or spring. } \\
\text { - } \quad \text { Post-extraction treatment requirements. }\end{array}$ \\
\hline $\begin{array}{l}\text { Cultural, } \\
\text { Institutional, } \\
\text { and Economic } \\
\text { Conditions }\end{array}$ & $\begin{array}{l}\text { - } \\
\text { - } \\
\text { - } \\
\text { - } \\
\text { - } \\
\text { - } \\
\text { Instisting user acceptance of water conditional capacity to design, constructs, operate, and maintain the MAR project. } \\
\text { Availability of alternative supplies or storage and treatment options. }\end{array}$ \\
\hline
\end{tabular}

\section{Case Studies in Applying the Elaborated Factors at the National Scale: Jordan 1990-2017}

Currently, Jordan's entire groundwater basins and aquifers are affected by groundwater-level decline and pollution [35]. The population in Jordan has grown from 1.75 million in 1970 to 6.4 million in 2010 [28], whilst water use has increased from $437 \mathrm{MCM}$ /year to around $950 \mathrm{MCM} /$ year [28,29]. Therefore, a MAR has become an attractive option and it has been studied, planned, and in a few cases implemented, as shown in Table 2. The knowledge from past MAR studies and implementation in Jordan, combined with the extensive research into the hydrogeological, economic, and cultural conditions provide a unique opportunity to analyze the potential for MAR at the national scale, as shown in Figure 2.

The collection of flood water in open-air reservoirs exposes the collected water to evaporation, which potentially ranges from $2400-4400 \mathrm{~mm}$ /year as long-term evaporation [36]. The arid areas are relatively flat, and the weir and dam reservoirs are relatively shallow (up to a few tens of meters in depth), so they cover a relatively large surface area resulting in strong evaporation. 
Table 2. Existing and studied (but not yet implemented) managed aquifer recharge projects in Jordan.

\begin{tabular}{|c|c|c|c|c|c|}
\hline Name of Site & $\begin{array}{l}\text { No. of } \\
\text { Structures }\end{array}$ & $\begin{array}{l}\text { Capacity } \\
\text { MCM }\end{array}$ & Intended Use & Actual Use & $\begin{array}{c}\text { Comments and Source of Recharge } \\
\text { Water }\end{array}$ \\
\hline $\begin{array}{l}\text { Madonnah and } \\
\text { Butum (W) }\end{array}$ & 3 & $0.003-0.066$ & $\mathrm{R}$ & $\mathrm{R}$ & Oversized by 7-fold (F) \\
\hline Mugheir (W) & 3 & $\begin{array}{l}0.015,0.016 \\
\text { and } 0.017\end{array}$ & $\mathrm{~S}$ and $\mathrm{R}$ & $\mathrm{S}$ and $\mathrm{R}$ & University of Jordan study site (F) \\
\hline Rajil (Da) & 1 & 3.4 & $\mathrm{R}$ & I and limited $\mathrm{R}$ & Bottom of low permeability (F) \\
\hline Jardaneh W & 1 & 0.35 & $\mathrm{R}$ & & Not constructed, low infiltration $(\mathrm{F})$ \\
\hline Swaqa (Da) & 1 & $\begin{array}{l}\text { Not given, } \\
\text { estimated 2.0 }\end{array}$ & $R$ and $I$ & I & High evaporation, low infiltration $(\mathrm{F})$ \\
\hline Kafrain (Da) & 1 & 7.5 & I & I and $\mathrm{R}$ & $\begin{array}{l}\text { Water harvesting project for irrigation } \\
\text { proved to be leaky }(\mathrm{B}, \mathrm{F}, \mathrm{T})\end{array}$ \\
\hline Shueib (Da) & 1 & 2.3 & I & I and $R$ & $\begin{array}{l}\text { Water harvesting project for irrigation } \\
\text { proved to be leaky }(\mathrm{B}, \mathrm{F}, \mathrm{T})\end{array}$ \\
\hline Wala (Da) & 1 & 9.3 & $\mathrm{D}$ & $\mathrm{D}$ & $\begin{array}{c}\text { Water harvesting project for irrigation } \\
\text { proved to be leaky }(\mathrm{F})\end{array}$ \\
\hline
\end{tabular}

W: Weir, Da: Dam, R: Recharge, S: Supplementary irrigation, D: Drinking, I: Irrigation, F: Flood, B: Base flow, T: Treated waste water.

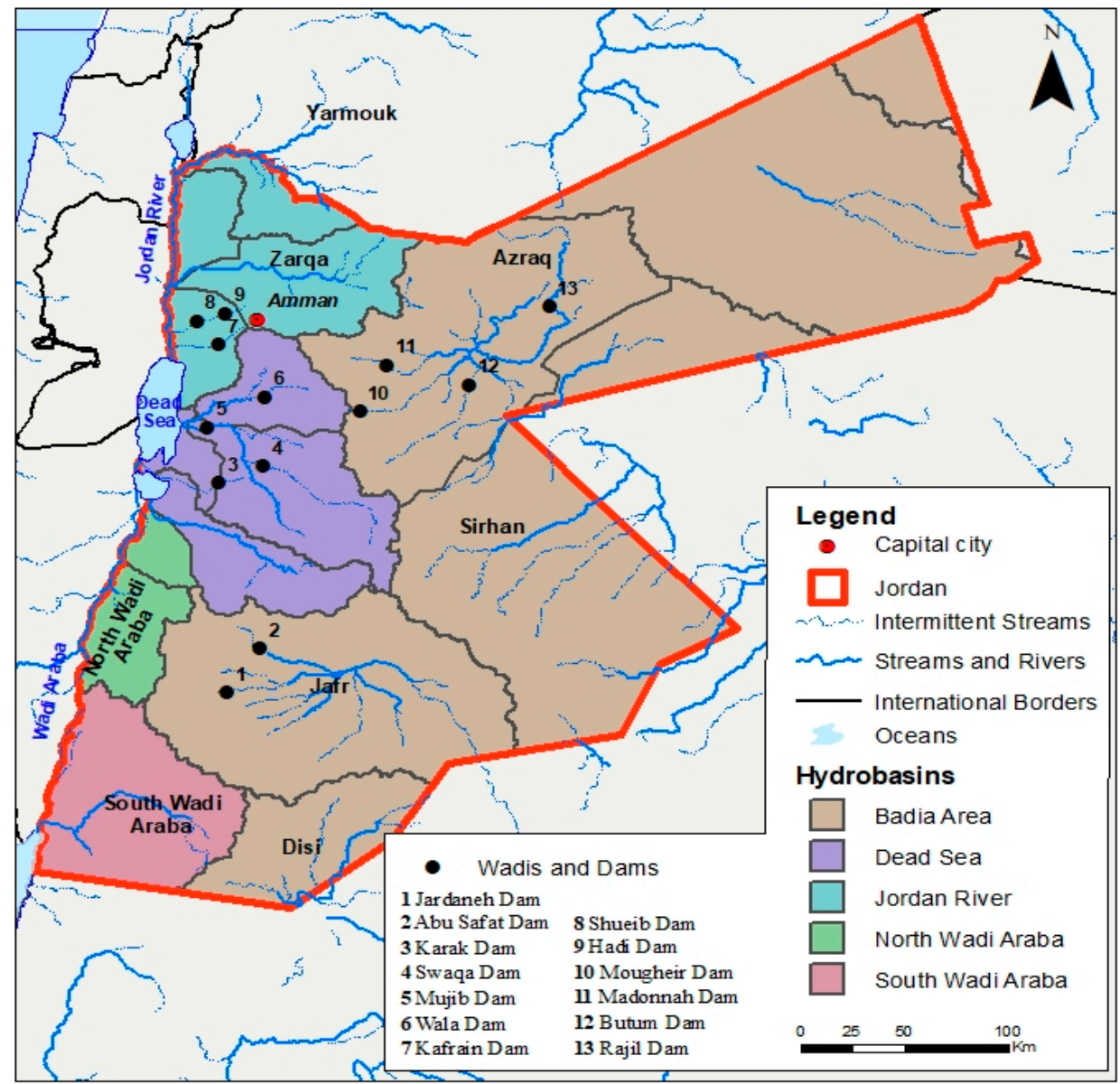

Figure 2. Sites considered for managed aquifer recharge in Jordan.

Not all side wadis on the eastern slopes of the Jordan Rift Valley are dammed, and the flood flows of these undammed wadis are lost to the salty Dead Sea water, irrespective of the positive impacts on the Dead Sea level, when left to naturally flow into it. In the Aqaba area, the significant fresh water floods of a barren area, mostly covered by a granitic basement complex, flow directly into the Gulf of Aqaba marine water, where the floods are lost as fresh water to saline environments. Catchments 
downstream of the dammed wadis discharge flood water unutilized into the Jordan River and the wadi Araba, and from there into the Dead Sea. Therefore, the storage of such water will increase the available resources for use by different sectors. Storage can take place as surface storage in dams, weirs, or pools, or as groundwater storage in an aquifer.

In Jordan, many studies have been carried out on the potential locations for a MAR in different parts of the country [30-33,35,37-39]. However, MAR projects have only been implemented at the wadi Madonnah [39], wadi Mugheir [40], and Wadi Rajil [29]. The other sites mentioned in Table 2 were not planned as artificial recharge projects, but they ended up fulfilling this purpose. The relevance of these sites for MAR will be discussed in Chapter 3.1 "Studied Sites" of this study.

In the current work, the previous studies on MAR sites are discussed in terms of relevance, and also in terms of fulfillment of the MAR conditions stated in Table 1. Moreover, the implemented MAR projects were evaluated, especially the leaky dams declared as MAR projects. The current study was based on geological, hydrological, hydrogeological, hydro-chemical, and geophysical studies and evaluations. New sites for MAR that fulfill the conditions for a successful MAR project were suggested.

\subsection{Studied Sites (Figure 2)}

\subsubsection{Highland Wadis}

\section{Wadi Madonnah and Wadi Butum}

The Ministry of Water and Irrigation (MWI) supported by the USAID carried out a general evaluation study on artificial recharge, which included more than 70 potential sites in Jordan. However, the study concentrated on the wadis Butum and Madonnah, which were studied in detail in 1995 [41].

Three weirs with a height of about $3 \mathrm{~m}$ and one weir with a height of about $6 \mathrm{~m}$ were constructed in-channel to collect floodwater for groundwater recharge by slowly releasing the water from the weirs for downstream infiltration into the groundwater.

The weirs were constructed along the wadi Madonnah located in the Badia area, South East (SE) of Amman, very close to the watershed which separates the Zarqa River catchment from the Azraq basin catchment. The catchment area of the wadi Madonnah is $37 \mathrm{~km}^{2}$ [41], with an average long-term precipitation of $169 \mathrm{~mm} /$ year [36]. The project was aimed at obtaining technical and practical experience on the recharge of floodwater, which can practically be achieved by constructing small weirs in the semi-desert area of Jordan.

The capacities of the weirs ranged from around $2000 \mathrm{~m}^{3}$ to $66,400 \mathrm{~m}^{3}$. The evaluations showed that the weirs were up to 7 times larger than necessary [41]. The average surface runoff from the catchment during the study period (2009-2011) was $6 \mathrm{~mm} /$ year or $3.5 \%$ of the average annual precipitation. De Laat and Nonner [37] concluded that the artificial recharge of such a small amount did not seem relevant. However, the authors' also rightly concluded that even a small amount of recharge can be relevant for a water-scarce country like Jordan. They mentioned that the alternative was the loss of surface water to a low-quality water body downstream.

However, the question to be asked of MAR initiatives relates to the fate of the floodwater if it were left to flow along its natural course along the wadi. How much of that water would have naturally infiltrated and recharged the groundwater? How large would the evaporation losses from the recharge dams' surfaces have been? The answers to these questions are discussed in the Discussion Chapter of this study. In conclusion, what matters is the final fate of the water.

\section{Muwaqqar Area, Wadi Mugheir}

Wadi Mugheir lies in the catchment area of the Azraq basin. The wadi was chosen for a water harvesting project by the Faculty of Agriculture at the University of Jordan, and it was financially supported by the European Commission (Project No: TSD-A-131-HKJ-(H)). Along the wadi Mugheir, $40 \mathrm{~km} \mathrm{SE}$ of Amman, three successive weirs were constructed in 1986 (coordinates: $31^{\circ} 46^{\prime} 42 \mathrm{~N}$, 
$36^{\circ} 13^{\prime} 00 \mathrm{E}$ ) to collect flood flow water for use in supplementary irrigation. These weirs offered an opportunity to study artificial recharge in a semi-arid area in Jordan.

The catchment area of wadi Mugheir, upstream of the weir sites, measures approximately $70 \mathrm{~km}^{2}$ and receives an average amount of long-term rainfall of 150 to $200 \mathrm{~mm} /$ year [36]. The soil type and sparse vegetation cover allow for a large portion of the precipitation to flow as surface runoff to the wadi, causing short intensive floods. The area is covered by limestone with some chert beds intercalations of tertiary age. The course of the wadis is covered by thin and compacted clastic sediments that are mainly composed of gravel and breccia.

The topography of the area is weakly undulating with some isolated hills. The capacities of the weirs to the spillway and the reservoir surface areas are as follows:

- Weir 1 (upstream): $15,580 \mathrm{~m}^{3}$ and $7200 \mathrm{~m}^{2}$.

- Weir 2 (middle): $14,860 \mathrm{~m}^{3}$ and $6000 \mathrm{~m}^{2}$.

- Weir 3 (downstream): $16,560 \mathrm{~m}^{3}$ and $8650 \mathrm{~m}^{2}$.

Evaporation was measured at a station installed in the study area, and the water extraction from the weirs for irrigation (in the dry season) was measured. The remaining drop in the water levels of the weirs was attributed to infiltration.

The weirs were filled several times a year. Infiltration rates ranged from 50 to $60 \mathrm{~mm} /$ day. In the year 1988, the infiltration amounts in the three weirs (1-3) were 82,000; 25,770; and 59,800 $\mathrm{m}^{3}$, respectively. In the year 1989, the infiltration in weirs 1 and 3 decreased, but not in weir 2 . It seemed that siltation had somehow affected the infiltration rate.

From this site, two lessons were learnt namely:

- Siltation of the bed/foundation/base of the weir is an issue which must be considered seriously when planning such weirs. Measures to minimize siltation or to remove accumulated silt must be in place.

- Flood water in the upstream wadi areas may naturally infiltrate if left to flow along its natural course to the base level making MAR unnecessary in the area, unless other purposes are targeted. For the cases listed in Table 2, this applied to the wadis Mugheir and Madonnah-Bottom. The other recharge sites lay in the downstream areas of the wadis, where, if the water flow is not captured, it will be deposited to the saline water bodies.

Rajil Dam

This dam was constructed on the wadi Rajil, which drains a small basalt area in Syria, as well as a large one in Jordan, with a total catchment of about $324.3 \mathrm{~km}^{2}$. The location of the dam is a few kilometers upstream of its discharge into the Azraq Oasis, which results in gaining of the flood water before it is collected in the drying oasis of Azraq and becoming impaired in its quality.

The height of the dam is $9 \mathrm{~m}$, its storage is $3.4 \mathrm{MCM}$, and it has an infiltration rate of $140 \mathrm{~L} / \mathrm{s}$ when filled with a surface area of around $950,000 \mathrm{~m}^{2}$. The dam partly served its purpose as a water harvesting project, because the dam lake bed proved to be of low permeability. Now the dam partly serves as a recharge dam and partly as a water harvesting project for local use by Bedouins. No studies have been concluded on the effects of the dam on the groundwater downstream, to evaluate the efficiency of that dam.

Other Sites

Other studies were conducted on the highland wadis discharging into the desert playas or at the heads of wadis discharging into the Rift Valley, such as:

- Jardaneh dam: The catchment area measures $222 \mathrm{~km}^{2}$, the dam's capacity is $0.35 \mathrm{MCM}$, with an evaporation rate of $6.1 \mathrm{~L} / \mathrm{s}$ and an infiltration rate of $1.9 \mathrm{~L} / \mathrm{s}$ when filled. Therefore, it was concluded that the dam was not feasible, and it was not constructed. 
- Swaqa dam: Catchment area measures $450 \mathrm{~km}^{2}$. The calculated evaporation from this dam proved to be very high at $14 \mathrm{~L} / \mathrm{s}$, compared to an infiltration of $0.1 \mathrm{~L} / \mathrm{s}$ when filled. The dam is currently used for local irrigation.

- Wadi Abu Safat: The reservoir area is considered too big compared to the water depth. It has an evaporation rate of $8.4 \mathrm{~L} / \mathrm{s}$ and an infiltration rate of $0.4 \mathrm{~L} / \mathrm{s}$ when filled, as measured by infiltration tests in the area. Therefore, it was concluded that the dam was not feasible, and it was not constructed.

\subsubsection{Wadis Draining Towards the Jordan Rift Valley}

\section{Wadi Kafrain}

Wadi Kafrain is a perennial water course fed by several small and big springs. The groundwater along the wadi course is generally effluent. Therefore, artificial recharge along its main course would be irrelevant, and the collected water would be contaminated by mixing with the wastewater. Although potentially useful for irrigation, it cannot be used for domestic supply without intensive treatment. This also applies to its different tributaries, where the groundwater is also effluent. Therefore, surface water storage in small dams is the only option relevant to this wadi catchment. The situation is different when the wadi Kafrain enters the Jordan Valley area, where recent clastic sediments cover the bottom of the wadi, such that groundwater recharge would be possible here.

The Kafrain dam was built in 1968. Its lake has a capacity of 3.8 MCM and it was meant to collect water from the wadi Kafrain for use in irrigation in the Jordan Valley area by gravity flow. After construction, the dam bottom and abutment proved to be leaky due to karstic limestone, and therefore, the water that was collected behind the dam easily found its way into the Jordan Valley deposits and to the adjacent ground surface as upwards leaking water. The leaking water is diverted and used together with the extracted water from wells in the dam's down-stream area for irrigation. It appears that the geological studies for the construction of the dam had been inadequate. The geological setting at the dam bottom and its reaches is highly fractured and karstified.

Wadi Shueib

The case of wadi Shueib is very similar to that of wadi Kafrain. A dam with a capacity of 2.3 MCM was constructed at its entrance into the Jordan Valley area to collect the perennial runoff. The measured average flood of the wadi is $1.8 \mathrm{MCM}$ /year and the base flow is $3.9 \mathrm{MCM} /$ year. Similarly, the reservoir bottom proved to be leaky and significant amounts of the collected water in the dam have infiltrated to recharge the alluvial deposits in the Jordan Valley area. The main difference with the Kafrain dam is that the bottom sediments of the Shueib dam mainly consist of clastics and not karstic limestone, thus the water flows slower. In the downstream area of the dam, the recharged water is extracted through wells and it is used for irrigation.

Al-Alami [37] studied a tributary of the wadi Shueib, i.e., wadi Hadi, for the construction of weirs to capture floodwater for storage and artificial recharge. The study proposed a sequence of weirs to be established on the side wadis of the wadi Hadi. The weirs were thought to minimize soil erosion and to reduce flood velocities, thereby increasing the recharge of groundwater, which improved environmental conditions. The study concludes that the weirs had very large positive impacts on the environment in general, and on increasing the available water, as well as being inexpensive. The aquifer to be recharged is the Amman-Wadi-Sir composite aquifer, which is the main aquifer in the western highlands and it runs along the wadi Shueib and its tributary the wadi Hadi, from where good water quality springs issue.

The average infiltration rates for the different geologic units covering the area were given in Reference [30]:

- Wadi Sir Formation (A7): $3.4 \mathrm{~m} /$ day,

- Shueib Formation (A5-6): 1.8 m/day, 
- Fuheis Formation (A3): $3.4 \mathrm{~m} /$ day.

\subsubsection{Wadis Discharging Directly into the Dead Sea}

Floods of the side tributaries of the main wadis discharging into the Dead Sea can be stored in dams or weirs before reaching the main wadi. This is because the floodwater when flowing along the main wadi, will generally only add to the discharge of the main wadi and it will not result in any infiltration to recharge aquifers, especially because the groundwater aquifers along the main wadis are generally effluent (Figure 3). Therefore, recharge structures along the wadis discharging into the Dead Sea might be appropriate for storing flood and base flow waters. The topography of the eastern slopes to the Dead Sea is very steep, where it declines from about 900 m.a.s.l. at the highlands to around $430 \mathrm{~m} . b . s .1$. at the shores of the Dead Sea (-430 $\mathrm{m}$ in 2016), within a distance of 10-15 km, or a slope of $10 \%$ to $13 \%$.

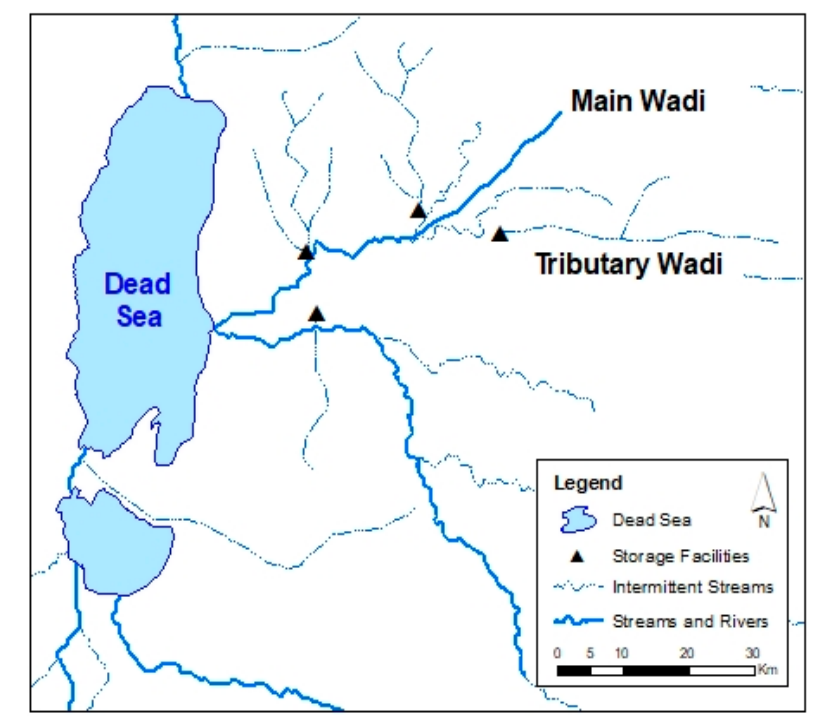

Figure 3. Potential surface storage facilities are very appropriate to collect flood water, but no potential for MAR, except some bank storage, because the groundwater of all aquifers in the area is effluent as a result of the strong slopes of the escarpment and the Dead Sea being the ultimate base level of all surface and groundwater resources of the Dead Sea catchment.

Wadi Karak

Al-Alami [30] studied in detail the potential of weirs as a dam substitute for surface water storage and artificial recharge in the Karak area. Wadi Karak, which drains the wadi Karak catchment, flows directly into the Dead Sea. It possessed at that time no dams, such that all the runoff went into the Dead Sea. Along the wadi Karak and its side wadis, such as the wadi Sufsaf and the wadi Rakin, water harvesting, as well as recharge weirs, were suggested to capture the flood and base flow [42].

The catchment areas of the side wadis range in extension from about $2 \mathrm{~km}^{2}$ to $15 \mathrm{~km}^{2}$, and those of the suggested weir sites on the wadi Karak proper range from $35 \mathrm{~km}^{2}$ to $47 \mathrm{~km}^{2}$. The infiltration rates of the weir sites range from $10^{-4}$ to $1.7 \times 10^{-3} \mathrm{~m}^{3} / \mathrm{s}$, using a vertical conductivity coefficient of $10^{-6} \mathrm{~m} / \mathrm{s}$ [43-45]. Four weirs were designed with depth-area-volume relationships. The relations of the infiltration rates and water depth were prepared.

Construction of 12 weirs was suggested in the wadi Karak tributaries to collect the flood and unused base flows of the wadis. The sites were generally upstream of the side wadis confluence into the main wadi Karak, which was very relevant to the MAR artificial recharge schemes. This is because once the flood or base flows reach the main wadi, the water will become lost to the Dead Sea because the groundwater along the wadi Karak is effluent and no infiltration is possible, except for some bank storage of reservoir lakes. 
Lateral infiltration was expected to be more efficient than vertical infiltration, especially when the weir reservoirs extensively extend upstream of the weirs.

The surface areas of the water collected in the weirs depends on the water height, and it is a function of the topography; therefore, the infiltration rates from the weirs bottoms increase with the water heads in the weirs. For the lateral conductivity, a value of $10^{-5} \mathrm{~m} / \mathrm{s}$ was used [44-46]. Bank infiltration of the weirs increased with water depth from $4.7 \times 10^{-6}$ to $1.4 \times 10^{-5} \mathrm{~m}^{3} / \mathrm{s}$ ) for a water depth of $0.5 \mathrm{~m}$ and to values between $3.6 \times 10^{-4}$ and $1.2 \times 10^{-4} \mathrm{~m}^{3} / \mathrm{s}$ for a water depth of $2.5 \mathrm{~cm}$.

Wadi Wala

In the upper reaches of the wadi Wala, the northern branch of the wadi Mujib, the Wala dam with a design capacity of $9.3 \mathrm{MCM}$ was constructed in 2002 to collect flood water from a catchment of approximately $2000 \mathrm{~km}^{2}$. Groundwater recharge was not the purpose of the dam. However, after starting the flood water collection, the water seeped very rapidly into the groundwater. The recharge volume according to Reference [46] of around $8 \mathrm{MCM} /$ year is recovered downstream of the dam through a series of extraction wells drilled into the Amman Wadi Sir karstic aquifer complex; B2/A7. The karstic nature of the aquifer in the area is reflected in the fast response of the groundwater levels in the downstream wells [47], in the increases of the karst spring discharges, which used to exist in the area before the drilling of the wells. The rapid response of the Wala springs and later the Wala wells discharge to changes in the water level of the Wala dam (hours) was a very good indicator of the reality that the dam was leaky. Nonetheless, more water is captured because the dam recharges water to the aquifer, rather than holding it in a reservoir that would incur evaporative losses.

The aquifer underlying the Wala dam area in the calcareous, joints, and karst cavities may be widened by the recharge or leaking water, which in the long-term (few tens of years), will result in land collapse and karst sinkholes.

The argument linked to the wadi Karak and wadi Wala cases also applies to all wadis that are discharging directly into the Dead Sea. There is no potential for groundwater artificial recharge, but surface storage and some bank storage may be possible. In addition, recharge in limestone terrains may add to karstification and its consequences on land stability.

\subsubsection{BGR-MWI Report}

The German Federal Institute for Geosciences and Natural Resources (BGR), together with the MWI in Jordan, carried out a study to develop guidelines for the assessment and implementation of groundwater artificial projects in the arid and semi-arid regions [48]. The study also addressed the prefeasibility of the infiltration of floodwater in the Amman Zarqa and Azraq basins in Jordan.

The guidelines were prepared to assist decision makers, funding agencies, interested stakeholders, and the scientific community involved in the artificial groundwater recharge projects, especially those in the semi-arid regions.

The Guidelines [48] addresses the following parameters relevant to managed aquifer schemes:

- Source water availability.

- Aquifer storage space.

- Effectiveness of the transfer of source water to the aquifer.

- Demand.

- Operation and maintenance.

- Monitoring.

- Economics.

- Institutions and management capability. 
Although regaining the recharged water was not addressed, it was understood from the context of the BGR-MWI report [48]. The BGR study was mainly concerned with two assessments (each comprising a constraint to groundwater recharge):

- The catchments' potential to generate adequate runoff, and

- The suitability of a selected site to harvest the flood water and to allow percolation into the aquifer.

Infiltration tests within that study were carried out by Salameh and Raggad, on tens of sites, in the semi-arid areas of the basins. The infiltration rates and grain size analyses are summarized in Figures 4 and 5 . The result could be summarized as follows:

- Specific site investigation must be carried out for each intended recharge scheme in accordance with a set of conditions developed in that study (BGR-MWI).

- Siltation remains the main problem of flood water recharge in arid- and semi-arid climates due to the turbidity of floods in such areas, which reduces when the velocity of the water decreases in the recharge facilities.

- Water heads in recharge facilities play a major role in the recharge.

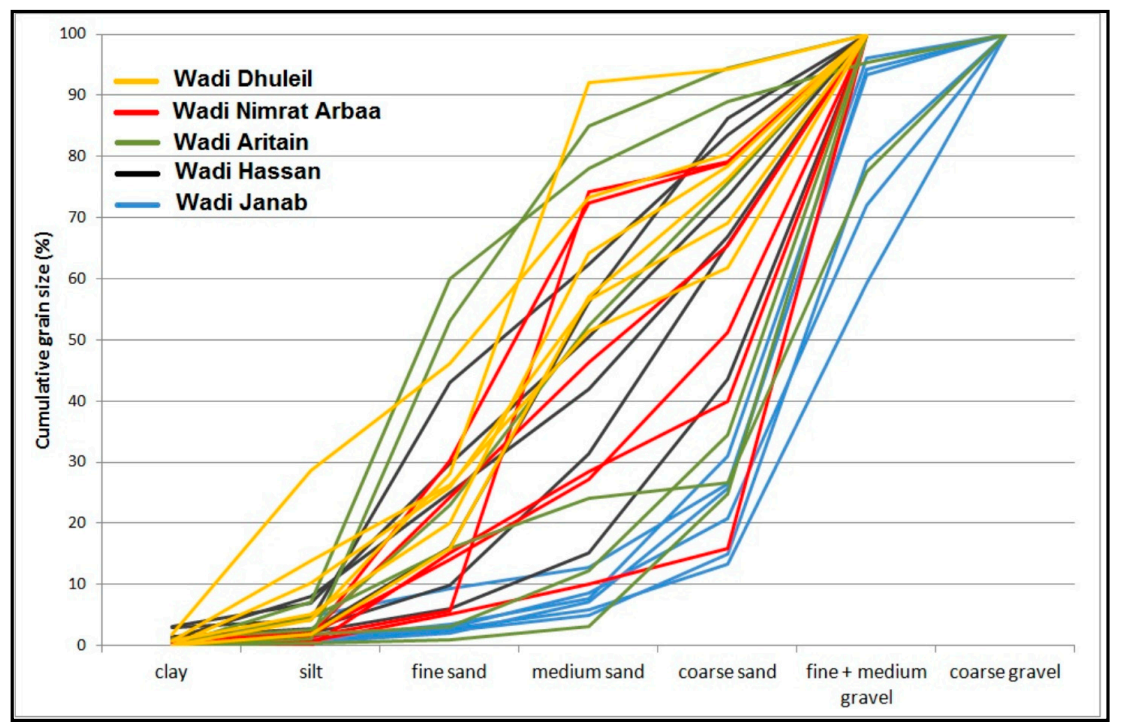

Figure 4. Cumulative grain size distribution of all the soil samples based on Reference [23].

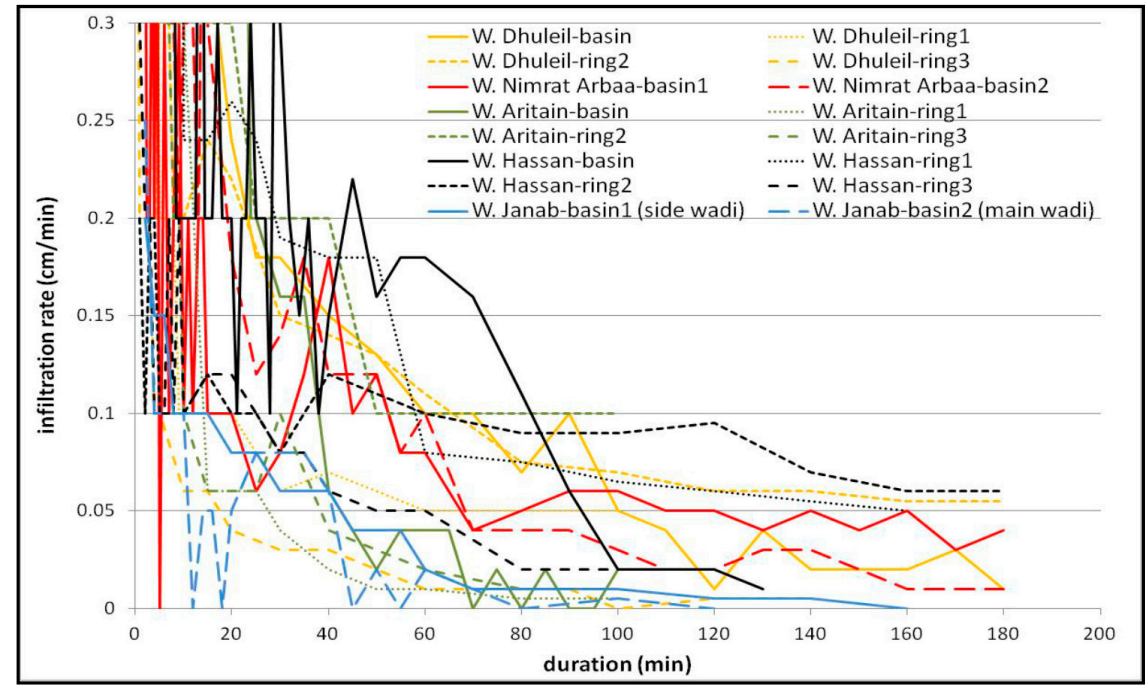

Figure 5. Development of the infiltration rate $(\mathrm{cm} / \mathrm{min})$ during the test duration based on Reference [23]. 


\section{Discussion}

\subsection{Potential for Artificial Recharge of Groundwater in Jordan}

Surface water in Jordan has seven final destinations:

- Azraq Oasis.

- Jafr depression.

- Sirhan Depression.

- Small playas accommodating up to a few thousand of cubic meters of water.

- Red Sea.

- Infiltration to groundwater.

- The Jordan Rift Valley.

Destinations 1-4 are endorheic basins and are dealt with together because they have the same conditions in relation to groundwater recharge, and all of them end up in desert playas or pools.

The origin of the water, especially flood water, which can be used for recharge, is generally a few tens of kilometers from the discharge or base level site. For instance, floods in Azraq partly originate about $100 \mathrm{~km}$ away in Syria or from the area east of the Dead Sea eastern mountains at about an $80 \mathrm{~km}$ distance. Generally, infiltration and groundwater recharge take place along the wadi courses, which are mostly covered by clastic sediments with high infiltration rates. Therefore, MAR schemes in the upper reaches of the wadis may be obsolete because that water, which can be collected for recharge at a recharge facility in the upstream areas of the wadis, may naturally infiltrate along the wadi course if it is left to flow naturally along the wadi, due to the highly permeable clastic bottom sediments of the wadis. In other words, flood waters along the upper reaches of the wadis may infiltrate to the groundwater if left to naturally flow along the wadi courses. However, if the purpose of the recharge is something else, e.g., improving groundwater quality or alleviating salt water intrusions in upstream areas, then the recharge projects are justified.

An example is the wadi Mugheir dam, $70 \mathrm{~km}$ upstream of the Azraq base level. Infiltration rates are around $50 \mathrm{~mm} /$ day $\left(5.8 \times 10^{-4} \mathrm{~mm} / \mathrm{s}\right)$, which is the minimum of the infiltration rates along the natural water courses in that area [48]. The distance to Azraq is $70 \mathrm{~km}$ and the width of the wetted wadi course during floods is estimated to be $5 \mathrm{~m}$ (at a minimum), where the infiltration amount in a day would be $17.500 \mathrm{~m}^{3} /$ day. The time required by flood water to flow from Mugheir to Azraq (its destination) is $9 \mathrm{~h}$, calculated using Manning's Formula for water velocity. If for $9 \mathrm{~h}$, the flood water is present along the wadi (width of wetted wadi $5 \mathrm{~m}$, wadi length $70 \mathrm{~km}$, and infiltration rate $50 \mathrm{~mm} /$ day $=5.8 \times 10^{-4} \mathrm{~mm} / \mathrm{s}$ ), then the infiltration would be around $6600 \mathrm{~m}^{3}$. In Equation (1), based on Manning's equation [49], $\mathrm{V}$ is the velocity of the water, $\mathrm{R}$ is the hydraulic diameter (A/L), where $A$ is the area of the flowing water cross-section, and $L$ is the wetted length across the valley, $S$ is the valley slope, and $\mathrm{n}$ is the roughness coefficient (0.03).

$$
\mathrm{V}=\frac{\mathrm{R}^{2 / 3} \mathrm{~S}^{1 / 2}}{\mathrm{n}}
$$

Lesson: The calculation indicates that recharge facilities in the upstream areas of catchments may not be necessary because the flood water would infiltrate naturally into the groundwater along the wadi course.

\subsection{Artificial Recharge of Groundwater Along the Eastern Side Wadis of the Jordan Rift Valley Area}

Along all the side wadis of the Jordan Rift Valley, aquifers discharge their groundwater in the form of springs and seepages. Proposals for the artificial recharge of groundwater should be substantiated by detailed studies on the surface water and groundwater quantities and qualities, the hydrogeological setting, topography, etc. In this region, bank storage by dams and weirs, and the enhancement of 
spring flow are potential options, but that can only be done after detailed investigation into the quality of the infiltrating water and its impact on the quality of the groundwater.

In the downstream areas of the wadis, where the water reaches the more recent sediments of the Jordan Valley, hydrogeological and hydro-chemical conditions change, because the alluvial aquifers there have the capacity to accommodate recharge water and the recharged water will, from a qualitative point of view, not cause any degradation to the existing groundwater quality. Therefore, this area provides good conditions for aquifer recharge, especially for storage and extraction. In addition, it is in this area that the extra flood water, treated wastewater, or base flow water find no storage and are lost to the saline Jordan River and eventually to the Dead Sea.

Lesson: Artificial recharge before losing water to saline water bodies is imperative. Harahsheh [50] studied the possibilities of establishing new dams and weirs along the wadi Kafrain and its tributary wadis to separate the good-quality runoff from the treated effluents of the wadi Kafrain, which are stored together in the Kafrain dam. This current mixing has resulted in reduced water quality, which restricts its use only for irrigation. The author suggested five possible dam locations along the wadi Kafrain and its tributaries, with capacities ranging from $320 \times 10^{3} \mathrm{~m}^{3}$ to $510 \times 10^{3} \mathrm{~m}^{3}$, and a total capacity of $1.93 \mathrm{MCM}$. Some of the dam's water would certainty infiltrate downward and recharge the aquifers, but that water would enhance spring discharge in the area.

Lesson: The results of the study on wadi Kafrain apply to all side wadis of the Jordan Rift Valley from Aqaba in the south to the Yarmouk River in the north, and they can be summarized as follows in Table 3.

Table 3. Areas and Wadis to be considered for MAR.

\begin{tabular}{cccc}
\hline Area & Site Name and Coordinates & Potential for MAR & Comments \\
\hline $\begin{array}{c}\text { Jordan Valley } \\
\text { (Northern part) }\end{array}$ & $\begin{array}{c}\text { Yarmouk River, Wadi Ziglab, Suleikhat, } \\
\text { Wadi Shueib, and Hisban }\left(32^{\circ} 37^{\prime} 58^{\prime \prime} \mathrm{N},\right. \\
\left.35^{\circ} 45^{\prime} 55^{\prime \prime} \mathrm{E} \text { to } 31^{\circ} 51^{\prime} 29^{\prime \prime} \mathrm{N}, 35^{\circ} 44^{\prime} 07^{\prime \prime} \mathrm{E}\right)\end{array}$ & Very high & Alluvial fans \\
\hline $\begin{array}{c}\text { Jordan Valley } \\
\text { (Southern part) }\end{array}$ & $\begin{array}{c}\text { Along Wadi Araba }\left(30^{\circ} 40^{\prime} 12^{\prime \prime} \mathrm{N}, 35^{\circ} 35^{\prime} 50^{\prime \prime}\right. \\
\mathrm{E} \text { to }\left(29^{\circ} 40^{\prime} 24^{\prime \prime} \mathrm{N}, 35^{\circ} 06^{\prime} 28^{\prime \prime} \mathrm{E}\right)\end{array}$ & $\begin{array}{c}\text { High: restricted by recharge } \\
\text { water availability }\end{array}$ & Alluvial fans \\
\hline Al Jafr & Jafr Depression $\left(30^{\circ} 22^{\prime} 20^{\prime \prime} \mathrm{N}, 36^{\circ} 11^{\prime} 23^{\prime \prime} \mathrm{E}\right)$ & $\begin{array}{c}\text { High: restricted by recharge } \\
\text { water availability }\end{array}$ & Alluvial fans \\
\hline Sirhan Depression & Main Wadis $\left(31^{\circ} 00^{\prime} 41^{\prime \prime} \mathrm{N}, 36^{\circ} 59^{\prime} 30^{\prime \prime} \mathrm{E}\right)$ & Very high & Alluvial fans \\
\hline Azraq & Wadi Rajil $\left(31^{\circ} 54^{\prime} 24^{\prime \prime} \mathrm{N}, 37^{\circ} 10^{\prime} 07^{\prime \prime} \mathrm{E}\right)$ & High & Alluvial fans \\
\hline Aqaba & $\left(29^{\circ} 24^{\prime} 04^{\prime \prime} \mathrm{N}, 35^{\circ} 03^{\prime} 15^{\prime \prime} \mathrm{E}\right)$ & Very high & Alluvial fans \\
\hline
\end{tabular}

Lesson: Retention structures in the catchment area before reaching the foothills of the Jordan Valley can serve to separate good-quality flood and base flows from water with insufficient quality, such as wastewater and irrigation return flows. Thus, this can enhance spring discharge by increasing the water stored in the underground (e.g., perched water table) of the spring area. However, it cannot be used as a retention structure to enhance groundwater recharge because of a shallow groundwater table and the groundwater discharge situations in this area.

Lesson: Recharging groundwater before any water reaches the Jordan Rift Valley and subsequently becomes polluted is highly appropriate. It prevents excess water from being lost to the saline surface water bodies, such as the Jordan River or the Dead Sea.

As a result, the following can be said about the MAR along the foothills of the Jordan Rift Valley:

- Alluvial fans along the eastern foothills of the Jordan Rift Valley (Jordan Valley and Wadi Araba) as revealed by geologic mapping, geoelectric soundings, and boreholes [31,34] are extensive, covering areas of $\mathrm{km}^{2}$ and are very thick, 100s of meters. They contain the necessary space to accommodate the recharge water (high storage potentials).

- Clogging by silt and clay or algal materials remains an obstacle, but due to the large area of the potential recharge pools, the flatness of the bottom, the possibility of removing accumulated 
silt from the bottom, and the possibility of constructing pre-settling pools, the MAR becomes highly viable.

- The large area of excavations in the alluvial fans and their flatness allow for easy mechanical removal of accumulated bottom sediments during dry times.

- The settled sand, silt, and clay at the bottom of excavations serve as a trap for algal materials, which disintegrate in a few days. This makes recharge pools more suitable than any other recharge technique exposed to siltation and clogging.

- For wadis discharging into the Red Sea, there is a very high potential for MAR projects at a distance of, at least, a few hundred meters upstream of the wadi discharge sites into the Sea, where the area consists of extended alluvial fans.

\subsection{Leaky Dam}

Some constructed dams such as Wala, Kafrain, and Shueib proved to be leaky, and have later been declared as recharge dams, although that was not the intended purpose of their construction. Nonetheless, they serve as recharge dams in addition to their original purpose of storing flood water of the rainy season for use during the dry season.

\section{Conclusions}

\subsection{Considerations for the $M A R$}

In Jordan, a semi-arid country, MAR is gradually becoming more important as a water-saving measure and a way to alleviate the impact of climate changes on the stocks of groundwater resources. The reasons for this are:

- Water stored in dams has high evaporation rates, eutrophication processes, and more pollution accidents compared to underground storage.

- In winter time, flood water is lost because of the lack of storage facilities and dam construction is not possible all over the country, especially in small inter-catchments between major wadis.

- When it rains and there is no need for irrigation, the flood and base flows, in addition to treated waste water find no use and no storage facilities.

Based on this review the following can be concluded:

- Wadis draining into the Jordan Rift Valley drain the groundwater along the major parts of their course before they enter the Rift Valley. Hence, MAR is not feasible in the upstream areas of such wadis (Figure 6).

- MAR along the lower reaches of the wadi catchments, along the foot hills of the Jordan Rift Valley is feasible. The alluvial aquifer can accommodate large amounts of water and any water not stored there will be lost to the saline Dead Sea or the Gulf of Aqaba or to the salty Jordan River. The declining Dead Sea level has started to cause a lowering in the groundwater levels in the wider Dead Sea area, and along the Jordan Valley area. Therefore, groundwater artificial recharge in these areas can alleviate and counteract the drop in the groundwater levels.

- MAR along the upper reaches of the catchments of the wadis draining to east Jordan and ending in the playas, has low potential because that water may infiltrate naturally before it reaches its base level destination (generally a salty playa). MAR at the lower reaches of the catchments of such wadis draining to east Jordan and ending in the playas is highly recommended in such areas, at a few $\mathrm{km}$ before the excess water, e.g., flood water, reaches its destination, i.e., a playa or a salty water regime. 


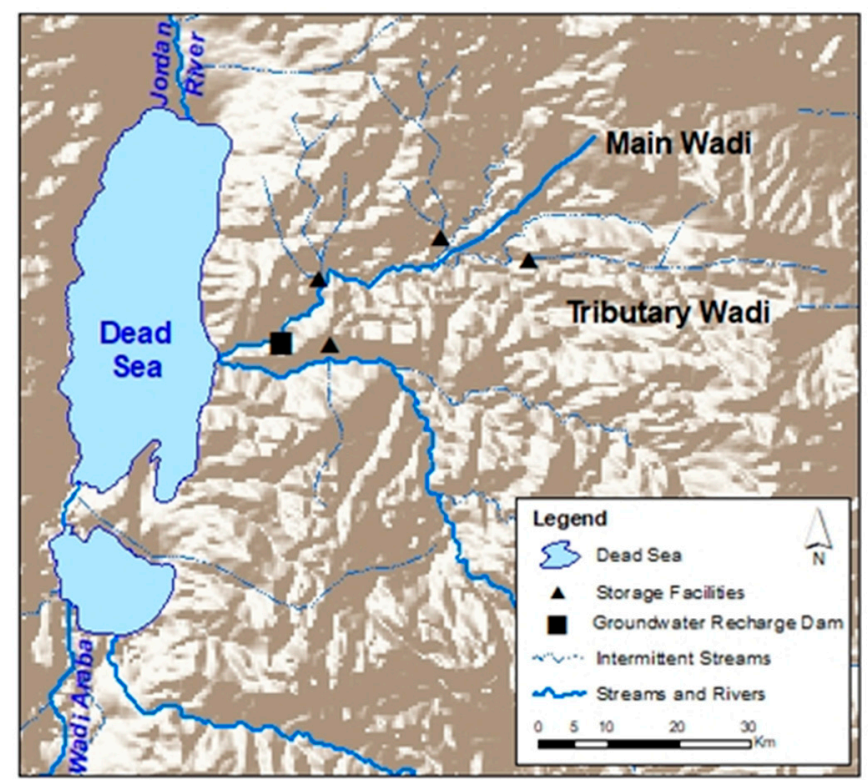

Figure 6. Along the main wadis discharging into the Jordan Valley and Wadi Araba groundwater recharge schemes are of high potential at the foot hills, where the main side wadis enter the Jordan Rift Valley. In the upstream areas, surface water storage has high potential, with some bank storage around the surface water reservoir. Owing to the effluent nature of the groundwater, along the upper reaches of these wadis groundwater recharge is not feasible.

MAR along the lower reaches of wadis discharging into the Gulf of Aqaba has high potential because:

- Dams in the area must be built on alluvial fans, and therefore, will be leaky and unstable from an engineering point of view.

- Very high potential evaporation rates (ca. $4400 \mathrm{~mm} /$ year).

- MAR can take place all along the wadis, which extend for 10 to $15 \mathrm{~km}$, and which are partly covered by thin alluvial coarse-grained sediments in their upper reaches (1-2 $\mathrm{m})$ and thick ones (few tens of meters) in their lower reaches, underlain by an impermeable granitic basement.

- Relatively low costs for recharge weirs compared to dams.

- In semi-arid areas, specific site investigations must be carried out for each intended recharge scheme, with special attention to the potentials of natural recharge if the water is left to flow along its natural course.

\subsection{Lessons Learned}

- In semi-arid areas, siltation remains the main problem, which can be partly solved by constructing a series of dams or weirs for water collection, settling of turbidity, and having one dam or weir for infiltration. Water heads in recharge facilities play a very big role in infiltration.

- In the case of Jordan, recharge wells (injection wells) as a method of MAR are excluded because of clogging problems when the flood recharge water is turbid or when the treated waste water containing organic matter particles causes clogging, unless adequate pre-treatment is provided.

- Unavailability of land along the deeply incised steep side wadis of the Jordan Rift Valley makes bank infiltration an improper choice, i.e., there are virtually no banks. Land application and excess irrigation are also not suitable if evaporation rates are high, with heavy use of fertilizers and biocides, and if the recharged water is intended for a use requiring higher quality water.

- Trenches and galleries are viable options for small recharge schemes of a few hundred or thousand cubic meters. Otherwise, they require extended areas of land and changes in the topography, thereby restricting the mobility of man and animals. 


\subsection{General Conclusions}

The lessons learned from the above case studies let us conclude the following:

- The hydrogeological setting should be studied well in advance of any MAR considerations. This includes water quality and water quantity aspects, as well as sediment.

- The vicinity of potential users of the water should be taken into consideration. Good MAR locations might be useless if there are no users nearby.

- The depth to the water table should be not too large, such that one loses the water, and not too small to be able to recharge any water at all. Hence, groundwater discharge regions are by definition not suitable.

Thick layers of relatively coarse sediment (e.g., alluvial fans, beds of ephemeral rivers, wide wadis) are beneficial for MAR. MAR can alleviate the impact of climatic changes on the availability of water in arid and semi-arid areas by increasing the stored amounts of groundwater, and the impacts of the declining Dead Sea level on its wider surrounding groundwater resources.

What has become clear from the successes and failures of MAR projects, whether planned or those that ended up as groundwater recharge projects, is that detailed studies of the hydrogeological setting and hydrochemistry are a prerequisite for a successful MAR project.

Author Contributions: Conceptualization, E.S. and G.A.; Methodology, E.S.; Software, G.A.; Validation, E.S. and G.A.; Formal Analysis, E.S.; Investigation, E.S. and G.A.; Resources E.S.; Data Curation, E.S. and G.A.; Writing-Original Draft Preparation, E.S. and G.A.; Writing-Review \& Editing, M.v.d.V.; Visualization, E.S.; Supervision, E.S.; Project Administration, E.S.; Funding Acquisition, E.S.

Funding: This research was funded by USAID-USGS grant number is G17AS00001.

Acknowledgments: This study has been done in the framework of the USAID-USGS project 'Acceleration of Aquifer Storage and Recovery in the MENA Region' that aims to find suitable locations for aquifer recharge in the Middle East. Funding by USAID grant number is G17AS00001. The authors would like to thank Jack Eggleston for all his help and suggestions.

Conflicts of Interest: The authors declare no conflict of interest.

\section{References}

1. Nasrat, A.; Al-Ansari, N. Mosul Dam Full Story: What If The Dam Fails? J. Earth Sci. Geotech. Eng. 2016, 6, 245-269.

2. Von Lossow, T. The rebirth of water as a weapon: IS in Syria and Iraq. Int. Spectat. 2016, 51, 82-99. [CrossRef]

3. Cunningham, E. Islamic State Jihadists Are Using Water as a Weapon in Iraq. The Washington Post, 7 October 2014. Available online: https:/ / www.middletownpress.com/nationworld/article/Islamic-State-jihadistsuse-water-as-a-weapon-in-11793224.php(accessed on 24 December 2018).

4. Salameh, E.; El-Naser, H. Changes in the Dead Sea level and their impacts on the surrounding groundwater bodies. Acta Hydrochim. Hydrobiol. 2000, 28, 24-33. [CrossRef]

5. Salameh, E.; E-Naser, H. The Interface Configuration of the Fresh-/Dead Sea Water-Theory and Measurements. Acta Hydrochim. Hydrobiol. 2000, 28, 323-328. [CrossRef]

6. Salameh, E.; El-Naser, H. Restoring the Shrinking Dead Sea-The Environmental Imperative. In Climatic Changes and Water Resources in the Middle East and North Africa; Springer: Berlin/Heidelberg, Germany, 2008; pp. 453-468.

7. Abou Karaki, N.; Closson, D.; Salameh, E.; de Tervaent, M.; Barjous, M. Natural, induced and environmental hazards along the Dead Sea coast, Jordan. Hydrogeologie und Umwelt 2005, 14, 1-25.

8. Dillon, P.J.; Pavelic, P.; Page, D.; Beringen, H.; Ward, J. Managed aquifer recharge. Introd. Waterlines Rep. Ser. 2009, 13, 86 .

9. Wolf, L.; Werz, H.; Hoetzl, H.; Ghanem, M. Exploring the potential of managed aquifer recharge to mitigate water scarcity in the Lower Jordan River Basin within an IWRM approach. In Proceedings of the 6th International Symposium on Managed Artificial Recharge of Groundwater, ISMAR6, Phoenix, AZ, USA, 28 October-2 November 2007; Volume 28. 
10. Salar, S.G.; Othman, A.A.; Hasan, S.E. Identification of suitable sites for groundwater recharge in Awaspi watershed using GIS and remote sensing techniques. Environ. Earth Sci. 2018, 77, 701. [CrossRef]

11. Khadija, G.; Anane, M.; Jellali, S. Geospatial and AHP-multicriteria analyses to locate and rank suitable sites for groundwater recharge with reclaimed water. Resour. Conserv. Recycl. 2015, 104, 19-30.

12. Ghodeif, K.; Paufler, S.; Grischek, T.; Wahaab, R.; Souaya, E.; Bakr, M.; Abogabal, A. Riverbank filtration in Cairo, Egypt-Part I: Installation of a new riverbank filtration site and first monitoring results. Environ. Earth Sci. 2018, 77, 270. [CrossRef]

13. Kaliraj, S.; Chandrasekar, N.; Magesh, N.S. Identification of potential groundwater recharge zones in Vaigai upper basin, Tamil Nadu, using GIS-based analytical hierarchical process (AHP) technique. Arab. J. Geosci. 2014, 7, 1385-1401. [CrossRef]

14. Gale, I. Strategies for Managed Aquifer Recharge (Mar) in Semi-Arid Areas. UNESCO. Available online: https:/ / unesdoc.unesco.org/ark:/48223/pf0000143819 (accessed on 24 December 2018).

15. Gale, I.; Dillon, P. IAH-MAR, International Association of Hydro Geologists-Managed Aquifer Recharge, Strategies for Managed Aquifer Recharge (Mar) in Semi Arid Areas; UNESCO: Paris, France, 2005.

16. Page, D.; Barry, K.; Regel, R.; Kremer, S.; Pavelic, P.; Vanderzalm, J.; Dillon, P.; Rinck-Pfeiffer, S.; Pitman, C. The aquifer storage, transfer and recovery project in Salisbury, South Australia. In Water Reclamation Technologies for Safe Managed Aquifer Recharge; IWA Publishing: London, UK, 2012.

17. Vanderzalm, J.L.; Page, D.W.; Barry, K.E.; Dillon, P.J. A comparison of the geochemical response to different managed aquifer recharge operations for injection of urban stormwater in a carbonate aquifer. Appl. Geochem. 2010, 25, 1350-1360. [CrossRef]

18. El Arabi, N. Environmental management of groundwater in Egypt via artificial recharge extending the practice to soil aquifer treatment (SAT). Int. J. Environ. Sustain. 2012, 1, 66-82. [CrossRef]

19. Kanarek, A.; Michail, M. Groundwater recharge with municipal effluent: Dan region reclamation project, Israel. Water Sci. Technol. 1996, 34, 227-233. [CrossRef]

20. Gangopadhyay, P.K.; Sharma, B.R.; Pavelic, P. Co-Solving Groundwater Depletion and Seasonal Flooding through an Innovative Managed Aquifer Recharge Approach: Converting Pilot to a Regional Solution in the Ram Ganga Sub-basin. In Clean and Sustainable Groundwater in India; Springer: Singapore, 2018; pp. 173-189.

21. Caldwell, T.G. Presentation of data for factors significant to yield from several riverbank filtration systems in the US and Europe. In Riverbank Filtration Hydrology; Springer: Dordrecht, The Netherlands, 2006; pp. 299-344.

22. Massmann, G.; Sültenfuß, J.; Dünnbier, U.; Knappe, A.; Taute, T.; Pekdeger, A. Investigation of groundwater residence times during bank filtration in Berlin: A multi-tracer approach. Hydrol. Processes Int. J. 2008, 22, 788-801. [CrossRef]

23. Schmidt, C.K.; Lange, F.T.; Brauch, H.J.; Kühn, W. Experiences with Riverbank Filtration and Infiltration in Germany; DVGW-Water Technology Center (TZW): Karlsruhe, Germany, 2003; Volume 17.

24. Sprenger, C.; Hartog, N.; Hernández, M.; Vilanova, E.; Grützmacher, G.; Scheibler, F.; Hannappel, S. Inventory of managed aquifer recharge sites in Europe: Historical development, current situation and perspectives. Hydrogeol. J. 2017, 25, 1909-1922. [CrossRef]

25. Van Dam, J.C. Exploitation, restoration and management. In Seawater Intrusion in Coastal Aquifers-Concepts, Methods and Practices; Springer: Dordrecht, The Netherlands, 1999; pp. 73-125.

26. Catalin, S.; Ansems, N. Web-based global inventory of managed aquifer recharge applications. Sustain. Water Resour. Manag. 2018, 4, 153-162.

27. Bower, H. Artificial recharge of groundwater: Systems, design and management. In Hydraulic Design Handbook; United State Department of Agriculture (USDA), Agricultural Research Services (ARS): Washington DC, USA, 1999; p. 44.

28. National Water Master Plan of Jordan (NWMP). Main Report and Updates. Natural Resources Authority of Jordan (NRA) and German Agency for Technical Cooperation (GTZ). Available online: http:/ / gis.nacse.org/ rewab/taggedDocs/National_Water_Master_Plan_of_2004_T.pdf (accessed on 25 December 2018).

29. Jordan Ministry of Water and Irrigation (MWI). Feasibility Report and Preliminary Design for Five Desert Dams. Geotechnical Description of Sites and Results of Field Investigations (MoWI and CID) Hydro Consult; Jordan Ministry of Water and Irrigation: Amman, Jordan, 1991.

30. Al-Alami, H. The Potential of Weir Use as Dam Substitute for Surface Water Storage and Artificial Recharge in Karak Area. Master's Thesis, University of Jordan, Amman, Jordan, 1996. 
31. Al-Amoush, H.; Salameh, E.; Al-Raggad, M. Hydro-Geoelectrical Investigation for the Potential of Underground Water Storage along the Lower Reaches of King Abdullah Canal—Deir Alla Area/Jordan. J. Water Resour. Prot. 2012, 4, 545. [CrossRef]

32. Al-Kharabsheh, A. Possibilities of Artificial Groundwater Recharge in the Azraq Basin: Potential Surface Water Utilization of Five Representative Catchment Areas (Jordan). Ph.D. Thesis, University of Würzburg, Bavaria, Germany, 1995.

33. Salameh, E. Possibilities of Utilizing the Yarmouk River Flood Waters in Groundwater Recharge. A Study Submitted to the Government of Jordan; Water Research and Study Center, University of Jordan: Amman, Jordan, 1990; 54p.

34. Salameh, E. The Potential of Groundwater Artificial Recharge in the Jordan Valley Area/Jordan: Selected Contributions to Applied Geology in the Jordan Rift Valley. Freib Forsch. Hefte C 2001, 494, 63-81.

35. Elias, S.; Shteiwi, M.; al Raggad, M. Water Resources of Jordan: Political, Social and Economic Implications of Scarce Water Resources; Springer: Cham, Switzerland, 2018; Volume 1.

36. Ministry of Water and Irrigation (MWI). Amman, Jordan, Open Files. Available online: http://www.mwi. gov.jo/sites/en-us/default.aspx (accessed on 25 December 2018).

37. Al-Alami, H. Watershed Management in Wadi Hadi (Jordan); Hydrogeologie und Umwelt: Würzburg, Germany, 1999; pp. 1-156.

38. Abu-Taleb, M.F. Recharge of groundwater through multi-stage reservoirs in a desert basin. Environ. Geol. 2003, 44, 379-390. [CrossRef]

39. De Laat, P.J.; Nonner, J.C. Artificial recharge with surface water; a pilot project in Wadi Madoneh, Jordan. Environ. Earth Sci. 2012, 65, 1251-1263. [CrossRef]

40. Salameh, E. Water harvesting and ground water artificial recharge. In AY Taimeh Report, Agriculture Production in the Semi-Arid Land and Areas Suffering from Desertification: Annual Report 1987-1988, October, 1988; University of Jordan Press: Amman, Jordan, 1988.

41. Chehata, M.; Dal Santo, J. Feasibility Study of Artificial Recharge in Jordan. Cases of Wadi Madoneh and Wadi Butum, Water Quality Improvement and Conservation Project; Ministry of Water and Irrigation (MoWI): Amman, Jordan, 1997.

42. Salameh, E. The Potentials of groundwater artificial recharge on the example of Muwaqqar and Wadi Karak areas. In Proceedings of the Regional Seminar on the Potential of Artificial Groundwater Recharge, WERSC University of Jordan, Amman, Jordan, 26-28 April 1993.

43. Salameh, E.; Shaqure, F. Geology and Hydrology of the Area West of Karak City, Jordan; University of Jordan Press: Amman, Jordan, 1981.

44. Rimawi, O. Hydrochemistry and Isotope Hydrogeology of the Ground and Surface Water NE of Mafraq Area (Dhuleil-Halabat-Azraq Basin). Ph.D. Thesis, Technical University of Munich, Munich, Germany, 1985.

45. Domenico, P.A.; Schwartz, F.W. Physical and Chemical Hydrogeology; Wiley: New York, NY, USA, 1998.

46. Sawarieh, A.; Hoetzl, H.; Wolf, L.; Ali, W.; Seder, N. Quantitative Effects of Artificial Recharge of Storm waters on Wala-Haidan Well Field. IWRM Management of Water in a Changing World: Lessons Learnt and Innovative Perspectives; International Congress Center: Dresden, Germany, 2011.

47. Pavelic, P. Use of Isotopes and Geochemical Techniques in the Study of Artificial Recharge in Groundwater. Advice on Design and Monitoring to Counterparts in Jordan, Syria and Yemen; IAEA Technical Co-Operation Expert Mission 19; International Atomic Energy Agency (IAEA): Vienna, Austria, 2005.

48. Steinel, A. Guideline for Assessment and Implementation of Managed Aquifer Recharge (MAR) in (semi-) Arid Regions: Pre-feasibility Study for Infiltration of Floodwater in the Amman-Zarqa and Azraq Basins, Jordan; BGR: Hannover, Germany, 2012.

49. Manning, R. On the flow of water in open channels and pipes. Trans. Inst. Civ. Eng. Irel. 1891, 20, 161-207.

50. Harahsheh, E. Hydrological Information Extraction for Dam Site Selection in Wadi Kafrein Catchment Area Using Geographical Information System. Master's Thesis, University of Jordan, Amman, Jordan, 2017.

(C) 2019 by the authors. Licensee MDPI, Basel, Switzerland. This article is an open access article distributed under the terms and conditions of the Creative Commons Attribution (CC BY) license (http:/ / creativecommons.org/licenses/by/4.0/). 